\title{
A metapoética do sonho em Bachelard: uma possibilidade hermenêutica das imagens do ar
}

\section{The methapoetics of the dream in Bachelard: A hermeneutic possibility of the images of the air}

\section{La metapoética del sueño en Bachelard: una posibilidad hermenéutica de las imágenes del aire}

Cabriel Kafure da Rocha ${ }^{1}$

Cleidimara Silva Madeira²

Recibido: 25 de julio de 2017 - Aceptado: 31 de agosto de 2017

\begin{abstract}
Resumo
O presente trabalho se propõe a examinar o problema de uma hermenêutica em Bachelard, por meio da leitura do texto $O$ ar e os sonhos. Nesse sentido, iremos trabalhar sob a perspectiva de que se é possível uma hermenêutica, quais as relações de ruptura e continuidade que esse saber tem com o hermetismo e posteriormente com a fenomenologia. Assim, pretendemos entender os limites e as margens que tal interpretação pode dinamizar em termos da imaginação simbólica em relação aos sonhos aéreos descritos pelo filósofo.
\end{abstract}

Palavras-chave: indeterminismo - onirismo - anima - imaginário - metapoética

\begin{abstract}
This present work proposes to examine the problem of a hermeneutics in Bachelard by reading the text Air and Dreams. In this sense, we will work from the perspective that if an hermeneutic is possible, what are the relations of rupture and continuity that this knowledge has with hermetism and later with phenomenology. Thus, we intend to understand
\end{abstract}

1 Brasileiro, Doutorando em Filosofia pela Universidade Federal do Rio Grande do Norte, Professor de Filosofia do Instituto Federal do Sertão Pernambucano. Contacto: gabriel.rocha@ifsertao-pe.edu.br

2 Braisleira, Graduada em Filosofia pela Cead da Universidade Federal do Piauí. Contacto: cleidimara25@gmail.com 
the limits and the margins that such an interpretation can dynamize in terms of the symbolic imagination and in relation to the aerial dreams described by the philosopher.

Keywords: Indeterminism - onirism - anima - imaginary - methapoetics

\section{Resumen}

El presente trabajo busca examinar el problema de una hermenéutica en Bachelard, por medio de la lectura del texto El Aire y los Sueños. En ese sentido, se trabajará sobre la perspectiva de que si es posible una hermenéutica, cuáles son las relaciones de ruptura y continuidad que ese saber tiene con el hermetismo y posteriormente con la fenomenología. Así, se pretende entender los límites y los márgenes que tal interpretación puede dinamizar en términos de la imaginación simbólica en relación a los sueños aéreos descritos por el filósofo.

Palabras clave: indeterminismo - onirismo - ánima - imaginario - Metapoética

\section{Considerações iniciais}

"A linguagem do sonho não está nas palavras, mas sim antes delas. Nela, as palavras são produtos acidentais do sentido, no qual se encontra a continuidade sem palavras de um fluxo. 0 sentido se esconde dentro da linguagem dos sonhos na maneira em que o faz uma figura dentro de um desenho misterioso."

Walter Benjamin

A presente investigação pretende se valer da questão de uma metapoética do ar como uma interpretação das metáforas apresentadas por Bachelard, por isso, investigaremos a obra $\mathrm{O}$ ar e os sonhos, pelas suas manifestações estéticas que nos levam ao cerne de uma hermenêutica por meio dos sonhos. Entendemos a metapoética ${ }^{3}$ como uma reflexão

3 "Sonhar-se-á, para tal, com qualquer metafilosofia, com um discurso mais geral mas de tipo ainda filosófico, sobre as metáforas de "primeiro grau", sobre as nãoverdadeiras metáforas que abriram a filosofia? O trabalho que se anunciaria sob o título de uma tal meta-metafórica não seria desinteressante. Acabaria, em suma, por transportar para a ordem filosófica o programa bachelardiano de uma "metapoética" (Derrida 1991 300). Nas Margens da filosofia Derrida expõe essa questão 
metafísica da poética, que nos exigira ir além da própria poesia, no sentido de entender a sua imaginação material, que no caso é representada pelo ar.

Para Bachelard, uma hermenêutica poética da imagem pode ser entendida como o confronto complementar entre ciência e arte, pela interpretação e as constituições de instrumentos essenciais da abertura das portas do universo do incompreensível. Por esse motivo, iremos partir justamente da ideia de um indeterminismo, para chegarmos à uma hermenêutica instauradora que proporcione as condições de leitura como uma dissecação dos fenômenos manifestos. Entendo que tal interpretação não é de uma fenomenografia, mas da própria criação fenomenotécnica, o que nos leva à uma hermenêutica da maneira como os poetas verbalizam esses fenômenos da vida, deformando-os e transformando em imagens. Segundo Bachelard, a imagem nasce pela sua deformação poética, ou seja, pela capacidade do poeta de verbalizar a natureza e transformá-la em imaginação. Esclarecendo que a imaginação é a faculdade de formar imagens, a faculdade de deformar imagens fornecidas pela percepção necessita do imaginário, e nisso, a filosofia se põe na tarefa de mediar a relação entre as metáforas "boas" e "ruins", que respectivamente podem se tornar conceitos científicos ou imagens poéticas.

A imaginação parece se retroalimentar do sonho, eis aí um caráter curioso, visto que as únicas obras poéticas referidas diretamente ao sonho em Bachelard são $A$ água e o sonhos e o $O$ ar e os sonhos. Curiosamente, é em $O$ ar e os sonhos que sua teoria se aproxima de uma hermenêutica, até porque, um exemplo disso é que nessa obra que ele fala sobre o caráter aéreo de Hermes ${ }^{4}$, esse deus que media

como o problema da meta-poética em que o próprio o conceito da imagem pela imagem, que Bachelard propõe inicialmente como pressuposto noturno só pode ser desconstruído. Nessa via, ele afirma que a imagem necessita de uma interpretação, consequentemente hermenêutica, e por isso ela se metaforiza, podendo considerar que uma boa metáfora que se destrói como conceito, já a má metáfora que se poetiza enquanto imagem deformada se eterniza.

4 Michel Serres, um dos alunos e orientados mais críticos em relação ao dualismo de Bachelard, em Luzes, faz uma série de menções a sua teoria de Hermes como um 
a comunicação entre os deuses e mortais. Nesse sentido, é provável que pesquisas mais críticas de Bachelard aleguem que nesse autor só seja possível falar de um hermetismo crítico. Entretanto, na medida em que a hermenêutica é um estudo ligado da interpretação entre a história biográfica e a história externa, o hermetismo se coloca numa maneira de um auto-conhecimento que necessita de uma psicanálise material para ser cientificamente legitimado. É na Poética do espaço que se encontra a única citação direta de Bachelard à hermenêutica:

É pelo espaço, é no espaço que encontramos os belos fósseis de uma duração concretizados em longos estágios. $\mathrm{O}$ inconsciente estagia. As lembranças são imóveis e tanto mais sólidas o quanto mais bem espacializadas. Localizar uma lembrança no tempo não é uma preocupação de biógrafo e quase corresponde exclusivamente a uma espécie de história externa, a uma história para uso externo, para comunicar aos outros. Mais profunda que a biografia, a hermenêutica deve determinar os centros de destino, desembaraçando a história de seu tecido temporal conjuntivo sem ação sobre nosso destino. (Bachelard 1993203 - grifos nossos).

Já o imaginário se dá quando se pensa, sonha ou vive-se a matéria, é interessante que a materialidade poética imaginária de Bachelard está baseada nos elementos (stoikheion) ${ }^{5}$ na medida que designa

vôo veloz entre a narrativa dos acontecimentos e uma mensagem que luta contra os ruídos do conhecimento. "Metáfora significa, justamente: transporte. Esse é o método de Hermes: ele exporta e importa, portanto atravessa; ele inventa e pode se enganar, devido à analogia, perigosa e mesmo, a rigor, proibida, não se conhece contudo outra via de invenção." (Serres 1999 90). O hermetismo que ele se refere é justamente a interpretação de uma hermenêutica pluralista e coerente, ou seja, a interpretação que não cessa de inventar novos sentidos.

5 "o stoikheion, o último elemento, faz parte da lexis, mas não possui em si qualquer sentido."(Derrida 1991 277). Nesse passo, o sentido dos elementos carece de lexis, ou seja, linguagem, mas não invalida que haja uma interpretação. Tal como o pesquisador "Jacques Derrida argumentou em 'Mitologia branca', que ao classificar as metáforas de origem, "em breve devemos recorrer a uma mitologia dos quatro elementos ", como fez Bachelard, mas que desta vez seria uma questão, 'Não de uma espécie de psicanálise da imaginação material envolvida com um corpus bastante indeterminado'" (Miles 2011 108). 
uma substância indivisível quanto à forma, contudo é também uma substância possível de se unir com outros elementos, gerando novas imagens. O imaginário não se encontra somente na imagem, a princípio tem necessidade de uma presença mais próxima, mais envolvente e mais material, por isso a natureza é a base para as metamorfoses da imaginação. Visto que Bachelard cria uma fenomenologia ${ }^{6}$ própria ou uma sistemática de investigação de gênese da imagem poética do imaginário literário. A partir de quatro elementos: água, ar, terra e fogo. Que regulam o real e o imaginário enquanto matérias arquetípicas do inocente alimentando pensamentos e sonhos. Identificados nas seguintes obras do autor com os subtítulos: A água e os sonhos: ensaio sobre a imaginação da matéria; $O$ ar e os sonhos: ensaio sobre a imaginação do movimento; $A$ terra e os devaneios da vontade e do repouso; e A psicanalise do fogo.

O ar e os sonhos, se constitui em uma obra nebulosa, até porque, é a partir das nuvens, sua instabilidade formal que partem tais devaneios. $O$ ar segue a tendência da verticalização do fogo, como uma simbolização transcendental do ser. Assim, subir e escalar se tornam as metas áereas, na medida em que o sonho do ar dá ao homem a vontade de voar, planar, flutuar. A simbologia que envolve o simbolismo desses estratos tem como principal obstáculo a gravidade. Contudo, o ímpeto do poeta-pensador bachelardiano não desiste e por isso, continua a sonhar e falar sobre o ar, como uma aporia necessária para respirar.

Na poética bachelardiana arquétipos são reservas do entusiasmo, possibilidade, do devir, ou seja, o sonhador cria imagens, cria o mundo. Nesse sentido, ele vai se valer da psicologia junguiana principalmente, por valorizar essas imagens simbólicas e tentar entender esse caráter universal arquetípico presente nessa perspectiva.

6 "De igual forma, esta fenomenologia é hermenêutica, prima pela interpretação dos fenômenos, inscreve-se num processo da ordem de um enfrentamento psicológico, sobretudo humano, pois consiste em uma atividade poética, estética" (Senicato \& Silva 2016 19). Desde essa percepção, defendemos que Bachelard avança para uma hermenêutica que considera a linguagem além da literal, é a atividade da interpretação das imagens, conceito e corpo. 
Nas configurações da imaginação poética é vivenciada e confessada pelo próprio filosofo, sendo a obsessão pelo elemento fogo que vai iluminar a epistemologia e metafisica poética de Bachelard. A hermenêutica em Bachelard partiria dos enunciados científicos, para daí retirar textualmente, inclusive novas significações do real, novas proposições de mundo. Muito mais que hermenêutica da tradição filosófica, Bachelard faz uma hermenêutica dos axiomas científicos. Na medida em que percebe-se Bachelard como hermeneuta dos fenômenos materiais, acredita-se entrar em consonância com algumas pesquisas que o desenham como construtor de uma nova episteme em Filosofia. Um Bachelard hermeneuta nasceria, justamente, como aquele que abre caminho para uma nova percepção e que coloca como centro desta abertura o cientista, o filósofo e inclusive o poeta que inova metodológica e epistemologicamente.

Iremos abordar os Complexos para Bachelard, como aquilo que se tece junto aos signos culturais que visam figuras míticas e literárias e sua associação com um determino elemento, um complexo é um fenômeno psicológico tão sintomático que basta um único traço para revertê-lo por inteiro. Um complexo é sempre uma articulação de uma ambivalência, existe um paradoxo do complexo em que toda cultura está carregada de complexos culturais, e isso se aproxima do sentido e imagens estereotipadas. Em torno de um complexo, a alegria e a dor estão sempre prontas a tocar sua dor.

Complexo: esta noção da psicologia significa a tez da psiquê e um conjunto de performances dolorosas que tecem (cum) - (plexus "com emaranhados"). [...] Seu uso da noção de que insiste na existência de certos complexos felizes, ao afastar a ortodoxia freudiana e estar mais perto do uso de Jung, que estava interessado nos arquétipos do inconsciente coletivo, e considerando a redução da abordagem freudiana em termos de libido. Depois de servir na classificação de imagens poéticas, ele é ancorado na estrutura do grupo das imagens na vida íntima dos poetas (Bontemps 2017 219). 
Desse modo, o complexo é a uma projeção de um elemento material que particulariza-se numa experiência cósmica. Tanto que os complexos estarão nomeados e ligados geralmente a nome de poetas tal como os complexos como de Novalis e Rilke, por exemplo, mas segundo a Prof. Luzia Oliveira, há mais de 150 complexos possíveis de serem enumerados na obra de Bachelard.

O céu e o sol representam o cume dos elementos ar e fogo, eles envolvem toda a terra, e é dessa manifestação energética que se tem a própria capacidade da visão. $\mathrm{Na}$ era do fogo, quando o homem podia se valer dele para dormir afastado dos animais, ele podia sonhar, já durante o dia, graças ao sol, ele podia olhar as formas e delas extrair suas formas em desenhos rupestres.

Ao mesmo tempo, é no aspecto mítico de uma queda do céu, do banimento do paraíso, que a cultura hebraico-cristã entende que surgiu a sua cultura. Bachelard entende que esse sopro da vida, que faz o homem respirar e apreender o ar, é a constatação de que tudo está no ar.

\section{0 ar}

\subsection{0 indeterminismo}

Desde a antiguidade grega, o ar denominado enquanto pneuma carregava junto com ele a noção de apeiron, ou seja, o indeterminado ${ }^{7}$. Nesse entendimento, o ar traz consigo a ideia de

\footnotetext{
7 "É por isso que, provavelmente, os textos bachelardianos ressoam tão bem no campo semântico dos "primeiros falantes" da filosofia: da "chamada physis", dos "enigmas da sabedoria" ou "poema do ser". A física arcaica assumiu o nome dos elementos para dizer a coisa que eles querem dizer a todos, incluindo os valores que o contexto cultural em que são adicionados, e pode-se dizer ainda uma "outra coisa" para a qual ela gradualmente se torna necessária inventando "ainda um outro nome." Que a palavra escolhida foi a apeiron = indefinido, on = o ser pronunciado com a força dinâmica do verbo, hen = um, ou arché = o princípio, em qualquer caso, esta é uma palavra muito simples, às vezes reduzida a uma sílaba, para dizer a coisa
} 
uma mobilidade incaptável de sentido, ele sopra para todos os lados e por não podemos vê-lo, só podemos medir os seus sentidos e direções.

Para os antigos, o ar era sempre o vento. Na experiência comum, se o ar é imóvel, ele perde de alguma forma sua existência. O vento é sempre uma força de união. É por isso que os movimentos desordenados da poeira em um raio de sol não são postos na conta do vento. [...]. O ar imóvel, é então o vazio intuitivo. Não há ação alguma, não é o sinal de nada, a causa evidente de nada. (Bachelard 1990 39).

Para trabalhar os imaginários aéreos, é preciso inspirar e expirar perante o abismo imaginário e entender em que sentidos que ecoa da verticalização. Desse modo, o elemento ar, de acordo com Bachelard, é fundamental para o entendimento desse processo da respiração como fundamento da vida.

As relações do vento e do sopro mereceriam um longo estudo. Encontraríamos aí essa fisiologia aérea tão relevante no pensamento indiano. Os exercícios respiratórios adquirem nele, como se sabe, um valor moral. São verdadeiros ritos que põem em relação o homem e o universo. O vento, para o mundo, e o sopro, para o homem, manifestam "a expansão das coisas infinitas". (Bachelard 1990 243).

Segundo Bachelard, o equilíbrio entre as metáforas da queda e da ascensão se dá, antes de qualquer referência moral, ao fato de que as impressões psíquicas do inconsciente deixam traços inegáveis. Bachelard, ao citar inicialmente o dinamismo do medo da escuridão, como uma relação com a queda. Relembra o fato de que boa parte das pessoas já sonharam que estão caindo e acordaram assustados, muitas vezes justamente caindo da cama.

no início, o comando, o princípio que gera a mitose dos pares de opostos, dentro do mesmo poder sob as extremidades de seu antagonismo" (Ramnoux 1979 535). 
Ele chama essa tendência psicológica como uma ligação com a verticalidade e é nesse prisma que devem se desenvolver os estudos sobre a queda. Para Bachelard, a queda faz parte da verticalidade, mas é para $o$ alto que se dirige o universo. Até porque, de certa forma, o universo não tem baixo, toda direção no universo, todo impulso é para algum lugar. De toda forma, essa força que aparenta impulsionar para baixo, a gravidade é o entre de toda a relação, é uma das forças essenciais do universo junto com o eletromagnetismo e as forças fracas e fortes.

Desse modo, "tonalizada moralmente, a queda já não pertence à ordem do acidente, mas da substância" (Bachelard 1990 93), ela envolve uma responsabilidade meditativa que reflete forças elementares como já vem sendo dito.

Bachelard considera que a imaginação da queda é, dessa forma, uma espécie de doença da imaginação. "Descer em vórtices e abismos sem luz para além de qualquer profundidade conhecida" (Bachelard 1990 95).

\subsection{Sonhos de vôo}

A relação entre o Ar e os sonhos se dá pela ideia do vôo, Bachelard começa a argumentar que a psicanálise costumou a entender os símbolos como conceitos, contudo, tal consideração reduziu o símbolo tende a ser analisado como uma categoria instrumental do inconsciente. Um exemplo disso é a célebre interpretação do sonho do vôo, como reflexo de uma psique de desejos voluptuosos ou mesmo de uma falta de firmeza psicológica, ou seja, o indivíduo que sonha que está voando era costumeiramente encarado como uma pessoa aérea, desligada e sem direcionamentos em suas metas e sonhos.

Bachelard vai desconstruir essa imagem ${ }^{8}$, até porque, para ele a imagem é um vetor importante para o pensamento e consequen-

8 "IMAGEM - A imagem poética está diretamente vinculada à imaginação. Sem esse élan vibrante e metamorfoseante da imaginação, a imagem não seria mais do que um objeto ou uma representação sensível da realidade. Ela é uma produção criado- 
temente, é pelas imagens positivas que se constrói uma teoria. Assim, é preciso encarar que o "vôo onírico tem necessidade, como todos os símbolos psicológicos, de uma interpretação múltipla: interpretação passional, interpretação estetizante, interpretação racional e objetiva" (Bachelard 1990 21).

Encaramos tal interpretação como uma tarefa hermenêutica, nesse sentido, o sonho de vôo é uma fonte amorosa de imagens, que carrega um porvir da essência da imagem aérea. Ele representa a viagem imaginária que carrega um dever psíquico substancial ligado à relação entre o ritmo da respiração e os estados psíquicos da alegria, dor, fadiga ou exaltação.

Dentro dos mitemas ligados à essa manifestação, obviamente Bachelard lembra de Ícaro, contudo, faz uma crítica ao vôo com asas, diz que tal projeção já representa uma técnica "a asa é já uma racionalização" (Bachelard 1990 27). Ao mesmo tempo "foi essa racionalização que originou a imagem de ĺcaro" (Idem).

Bachelard diz que o vôo onírico está ligado, quando ligado às asas, deve ser simbolizado pela imagem de Hermes, com asas nos pés, por simbolizar o trajeto entre mundos. Nos pés está a representação da impulsão da vontade de projeção. Ao passo que o sonho de asas batendo representa a queda, Mercúrio, ou Hermes, com suas botas de setes léguas "iremos designar, em nossas pesquisas de metapoética", essas asas no calcanhar sob o nome de asas oníricas" (Bachelard 1990 31).

ra e não reprodução. A imagem apresenta um duplo aspecto: interior e exterior. A exuberância das formas é determinada pela projeção da imaginação material e dos possíveis "fantasmas" que habitam o mundo do sonhador. Na obra sobre os elementos materiais, Gaston Bachelard procurou estudar as imagens em sua objetividade sem, no entanto, deixar de se preocupar com a subjetividade. A partir de A poética do espaço, preocupou-se em analisar a imagem em seu ser, em sua subjetividade como produto que emerge das profundezas, tendo como partida a consciência" (Ferreira 2013 96).

9 "Daí porque preferirmos o nome de 'metapoética' para caracterizar seu trabalho, do que a metafísica ou crítica literária. Porém, o essencial é que Bachelard encarna uma estética da atividade, que nos incita a também devanear, que nos encoraja a também sonhar. Por isso, a melhor crítica é também a melhor homenagem: aceitar o desafio e também lutar, também lançar a imaginação ao devaneio metapoético" 
É na imaginação dinâmica do movimento de subida e descida que Bachelard recolhe imagens aéreas, horizontes sem fim, espaços abertos, imensidões celestes, sonhos em vôo e de queda, mas principalmente do movimento desmaterializante e da verticalização do tempo. No chamado instante dinamizado da leveza e dos instintos mais profundos da vida.

Bachelard estabelece uma verdadeira filosofia da imaginação ao afirmar que a imaginação é o próprio ser, o ser que produz suas imagens e seus pensamentos. A imaginação dinâmica procede a imaginação material. Para Bachelard, não existe uma vontade que preceda as imagens, que as ilustra. Um desejo não existe senão através de uma imagem que o exprime. Não se pode separar a expressão de um desejo da respectiva imagem expressa.

Bachelard afirma que sua confiança no valor dinâmico das imagens literárias é que levam o leitor a sonhar e, por meio delas, aprender a sonhar bem, poeticamente. Para ele a imagem é a oportunidade de um nascimento sempre renovado, tem linguagem própria é uma modalidade de conhecimento dotada de um estatuto ontológico e irredutível ao conceito e a percepção aplicada a teoria da imaginação material e dinâmica a analises de diversos elementos como o ar, a terra, a água...

O ar é o significado da vida. A ele estão ligados todos os devaneios da vida aérea, do voo, da ascensão e da queda. $\mathrm{O}$ ar leva o sonhador para o ideal da liberdade que o voo ascensional indica e para o etéreo como ideal de espaço livre. $\mathrm{O}$ ar e o voo se interligam para levar a pessoa a desejar a transcendência, tornam-se um convite para a leveza, para a ascensão e, também, fazem com que o desejo de ascender torna-se o caminho de seu íntimo.

"O elemento aéreo é o próprio ser da mobilidade, encontrando, como oposição ao seu sonho de voo, a queda" (Silva 2011 58). Ao mesmo tempo em que o desejo de ascender traz a presença, ao sonhador, da leveza, em relação a verticalidade, pode também 
trazer a presença do peso em relação a queda, assinalando a ambivalência desse movimento, inclusive psiquicamente, quer dizer, levar o sonhador a dialética da euforia ou da angústia. As imagens aéreas mobilizam o ser, elas impelem o sonhador a agir, a ponto de Bachelard afirmar que, através do homem, os elementos podem sonhar, pois a natureza sonha e seu onirismo é a nossa realidade. Partindo então de um devaneio do vôo, em seu simbolismo do desejo voluptuoso, voar é estabelecer uma atividade profunda com o céu ou trazer o céu para dentro de nós, é colocar-nos no seio do universo e sonhar junto com ele.

\subsection{0 vento}

O vento é como elemento do devaneio oniríco, sonhador em sua profunda ambivalência de suavidade e força, poderá ser o símbolo da fúria da cólera, do poder enquanto tempestade ou furação. Esse vento em ambivalência que é doçura e violência, pureza e delírio, pode manifestar seu duplo ardor de destruição, de vida e de animação. O vento torna-se as metáforas poéticas da vida, da recuperação, da destruição, do poder, da suavidade e do movimento criado.

O vento, como elemento do devaneio onírico, sonhado em sua profunda ambivalência de suavidade e força, poderá ser o símbolo da fúria, da cólera, do poder enquanto tempestade ou furacão. Como na imaginação dinâmica, o movimento cria o ser, o turbilhão cria as estrelas, o grito produz a palavra, o pensamento (Castro 1991 106).

O vento, em Bachelard, pode ser entendido como a respiração cósmica, seu fenômeno é uma consequência do movimento de translação da terra nele está a movimento de criar e destruir, inspirar, trazer para si e para os outros o aprendizado, a inspiração. E a expirar, colocar para fora o cansaço e dar a leveza à vida. Filosofias como a budista e práticas como a Yoga enfatizam como na respiração ${ }^{10}$ está o segredo

10 Um exemplo disso é a técnica conhecida como terapia do renascimento, em que por meio de uma respiração considerada holotrópica, o ar faz com que a pessoa 
dos estados de ânimo, a calma, por exemplo, de respirar profundamente. Ao expirar abrimos espaço para renovar a energia virtual, esvazia-se a mente para torná-la apta a novos aprendizados. Assim, expirar é deixar-se na confiança do deixar ser.

"Todas as fases do vento têm sua psicologia. O vento se excita e desanima." (Bachelard 1990 236). Para o filósofo, o vento nasce de um sonho da terra, evocando a fúria das Erínias ${ }^{11}$, sua imagem carrega a ambivalência da doçura e da violência. O vento norte, Bóreas, rei dos ventos, nos leva para o frio e a neve, e o vento sul para o azul dos céus com a sedução do sol, o vento oeste para o oriente, e o leste para o ocidente. Os quatro cantos do vento representam a dialética do quente e do frio, do seco e do húmido.

\subsection{As nuvens}

"Nuvens: água em estado onírico. O alfabeto do céu." (Agualusa 2013 64). As nuvens constam-se entre os elementos poetizáveis mais oníricos, visto que desvelam o onirismo do pleno dia. Determinam devaneios efêmeros, por um instante aquilo que está "nas nuvens" é uma forma, logo, já não é. Mas é com as nuvens que a tarefa se torna a um tempo grandioso e fácil, o da transformação incessante do devaneio em sonho e vice-versa.

Quando começam a se mover as nuvens despertam em nós desejos inseparáveis, o movimento tem mais homogeneida-

tome consciência dos bloqueios energéticos do seu corpo, ou seja, possibilite uma interpretação corporal para desbloquear e curar suas tensões. Tal técnica desenvolvida por Leonard Orr mostra que "existe um momento em que a pessoa toma consciência de que está respirando a energia e o ar. Quando se dá essa compreensão na mente e no espírito do indivíduo, ele aprender a respirar. Isso é o que quero dizer quando chamo esse processo de respiração consciente. Esta equivale a estabelecer essa reação conscientemente no ritmo da respiração. Você funde o inspirar com o expirar." (Orr apud Minnet 1994 73).

11 Eram elementais, seres da natureza que representavam a vingança. Contudo, como existiam para punir os humanos, os humanos costumavam chamá-las de Eumênides (benevolentes), para não atrair a sua própria fúria. 
de onírica que o jogo poético pode realmente destacar. É o chamado "poder formal do amorfo" (Bachelard 1993 193), em que a atividade do poeta-filósofo é liberar uma matéria que quer sonhar. Matéria, movimento, necessidade e desejo em nossos intermináveis devaneios diante do céu, as nuvens carregam um segredo em sua suavidade, carregam blocos de gelo acima da gravidade. Tal materialidade das nuvens em movimentos que nos despertem os sonhos em movimentos vagarosos e redondos, movimentos brancos, movimentos que escoam sem rumo e acordam em nós uma vida de imaginação, mas que também relampejam uma eletricidade que deve ser respeitada, junto com as tempestades e a transformação do ar em água.

A imaginação das formas que é realizado pelas nuvens despertando imaginação, sejam elas nuvens stratus, cumulus, cerrus, e nimbus sempre despertam no ente que sonha o seu ser de sublimação total. Bachelard diz que Goethe é o poeta das nuvens, quando entende o Stratus como uma espécie de nevoeiro que se desdobra e eleva contra as montanhas em camadas rumo ao céu. O Cumulus representa a atmosfera, a esfera de vapor que envolve o globo terrestre protegendo a vida dos raios ultra violentos do sol. Cirrus é o amontoado de nuvens mais altas, o espaço da aviação da tropoesfera, é onde o tempo metereológico gira e se mistura, chegando até as turbulências. Nimbus é o destino da terra, onde o espírito eleva-se

No Nimbus suspenso entre a subida e a descida estão também em preparação muitos devaneios diferentes. De todo modo, ao ler Goethe, devemos reconhecer que o devaneio da nuvem não é inteiramente analisado pela contemplação das formas (Bachelard 1993 198).

As nuvens revelam desejos, afetos e símbolos intelectualizados, e esse é o alfabeto do céu na medida que são as pulsões que motivam as ações humanas. 


\subsection{0 céu}

O céu é tão simples que acreditamos não poder devaneá-lo sem materializá-lo. "Haveria, assim aqueles que vêem no céu um liquido fluente e animam-se com qualquer nuvem, os que veem o céu como uma chama abóbada pintada e consolidada e finalmente, os que realmente participam de sua natureza aérea" (Bachelard 1990 157). Fazer-se o céu azul demasiado, seja ele compacta, ardente e brilhante, por vezes, o céu azul nos olha demasiado fixamente. Atribuindo a ele demasiada substancia, porque a alma não se converte à vida da sustância primitiva.

Céu: todo o território onde a vida é mais leve do que o ar. Para os mais velhos, um lugar desprovido de passado, como existir o canto de uma ave, sem que exista a ave. $\mathrm{O}$ lugar para onde ascendem os sonhos, inclusive os maus (Agualusa 2013 6).

Para Bachelard, é interessante que mesmo para os poetas, a imagem do céu é utilizada como metáfora de uma doutrina da representação, de um simulacro entre a relação do visível e o invisível no ato da criação artística. Ele afirma que o ser, para tomar consciência de sua faculdade de representação, deve passar por um estado puro de devaneio ou admiração, onde o mundo imaginado situa-se antes do mundo real e o céu tomou lugar como esse mundo inteligível que antecede a nossa realidade. Olhar o céu é fixa-se apenas na imaginação, com os olhos irreais e virgens ignorantes do mundo e de si mesmo.

O céu é azul, e num infinito que se desdobra no azul da noite e do dia. "O azul designa, mas não mostra." (Bachelard 1990 163). Tal afirmação é a escala da desmaterialização do azul entre um simples fundo e a animação de uma metáfora. Por isso o céu é a condição da desmaterialização da imaginação do ar, é no céu que as nuvens se dissolvem e a noite chega para as estrelas brilharem. 
Aí está a importância do céu enquanto uma Einfülung ${ }^{12}$ aérea que não tem acontecimento, choque ou história, é espaço puro de um lugar antes da representação, o seu faz o mundo representação do ser que sonha antes de meditar. Que devaneia antes de contemplar. O céu azul é como uma miragem de um sonho do cosmos adormecido.

\subsection{Constelações}

Grupo de um certo número de estrelas fixas no céu. Onde o brilho das estrelas é como o fito que ajuda a memória. Supõem-se uma figura, quer de homem, quer de animal, quer de planta e se deu um nome para distingui-los dos demais grupos do mesmo espaço. A luz das estrelas tem um dos devaneios mais constantes, mais regulares, o devaneio do olhar. Conhecer as constelações, nomeá-las como livros, projetar sobre o céu um mapa escolar do céu, é brutalizar nossas forças imaginarias e retirar-nos o benefício do onirismo.

Duas estrelas gêmeas são já para nós um rosto que nos fita, e, numa exata recíproca, dois olhos que nos dão o seu olhar, por estranhos que sejam à nossa própria vida, têm sobre nossa alma uma influência estelar. [...] ver e olhar trocam aqui seu dinamismo, recebemos e damos. Já não existe distância. Um infinito de comunhão suprime um infinito de grandeza. O mundo das estrelas toca a nossa alma: é o mundo do olhar (Bachelard 1990 187).

Para Bachelard, todos os desenhos das constelações são devaneios matemáticos falsos, contudo, o traçado de linhas imaginárias das constelações são pontilhismos reduzidos, sonoridade de paisagens noturnas. Como imagens literárias puras de um movimento comum dos astros, num lento sono aéreo. As estrelas nos olham, pois tudo 
o que brilha é um olhar, na distância infinita do espaço estelar, os olhares se unem e se tornam constelações astrológicas. "A astrologia pode auxiliar como um conhecimento hermético de alguns aspectos interpretativos de uma psicologia indireta, tal qual o próprio Bachelard realizou em suas leituras poéticas e noturnas." (Rocha 2016 169).

A astrologia, se torna assim um tema polêmico para o contexto da visão das constelações, apesar de Bachelard ressaltar que a astrologia e alquimia são hermetismos ${ }^{13}$ entendido pelos termos das psicologias da causa, da probabilidade, do determinismo e/ou mesmo da forma, que tratam-se de psicologias indiretas que servem para analisar não o ser humano, mas os elementos naturais. Desse modo, muito mais do que falar sobre uma psique humana, a astrologia como leitura dos desenhos das constelaçãos e sua relação com a natureza, serviria mais para falar dos astros e dos elementos do que a consciência psicológica humana, isso dentro de numa perspectiva fenomenológica e talvez mesmo hermenêutica como confronto de interpretações das leituras estelares.

\section{Considerações Finais}

De acordo com nossas pesquisas, é possível falar em uma hermenêutica dos sonhos justamente por conta do texto de Gilbert Durand, em A imagem simbólica onde ele coloca Bachelard como um dos representantes de uma hermenêutica instauradora. Seu texto retrata justamente que a imagem se estuda pela imagem, $\mathrm{e}$ a hermenêutica de Bachelard supera a noção de simulacro nesse sentido, visto que é criação de imagens e não pura representação. Ele distingue uma boa e uma má utilização dos símbolos na medida em que a tendência de desfazer o símbolo do setor

13 "La alquimia considera que en el aire laten fuerzas invisibles. El aire tiene un fuerte poder en su naturaleza sutil. En tanto que aliento se inscribe en la naturaleza humana, es signo de salud y signo de vida." (Lapoujade 2009 54). Lapoujade também relembra que é no ar que se manifestam os cheiros, o que para Bachelard estão intimamente ligadas às memórias da infância, principalmente. 
dos sonhos é uma sintomática denunciadora de uma linguagem que não nasce mais.

\title{
Bachelard opera em um sobreconsciente ${ }^{14}$ poética permeado por palavras metáforas e fantasias.
}

\begin{abstract}
Por sua vez, Bachelard reserva à psicanálise o estudo do inconsciente, logo, dos sonhos noturnos. Estes últimos já não são «uma consciência», logo, não são passíveis da fenomenologia, são «factos». Esta distinção é capital, permitindo elucidar nitidamente o falso problema da «sublimação»: o sonho é infraconsciência, logo, submete-se à análise objectiva dos fatos, a fantasia criadora é sobreconsciência e a consciência que a ela se aplica é criadora precisamente por isso, e a hermenêutica (Durand1993 63).
\end{abstract}

Por essa via preferimos justamente entender o sonho dentro de um viés hermenêutico, não tanto de uma interpretação de sonhos tal como os dicionários usualmente tendem a psicologisar, mas sim como um aprendizado de sonhar. De aprender a lidar com essa possibilidade do grande vôo da alma, e diga-se que o ar é o elemento ligado ao ânima ${ }^{15}$, por isso se constitui em uma metade importante que completa o ânimus da individualidade.

Daí uma hermenêutica que, neste epistemólogo, paradoxalmente, já nada tem a ver com a análise, com o método das ciências da natureza. Bachelard mostrou-o constantemente

\footnotetext{
14 Vale fazer uma referência a essas palavras do vocabulário de Durand, a sobreconsciência não é o mesmo que o subconsciente, é uma consciência superior revelada pelo o que está além, como a natureza do ar. Já a infraconsciência é justamente o espaço do sonho, como aquela nuance homeostática que retroalimenta o imaginário. 15 Nesse sentido, é possível entender o ânima como um aspecto espacial, aliás, é o espaço do imaginário que não tem necessidade do tempo que é para o ânimus. E retomando o fato da única citação bachelardiana sobre hermenêutica ter se dado na Poética do espaço, isso é porque "sua hermenêutica do espaço é sobre a imaginação e os sonhos; [...] A hermenêutica do espaço de Bachelard oferece ao leitor uma exploração da nossa relação com aqueles espaços significativos para nós. Estes espaços são espaços sonhados que se alimentam e recriam os lugares de nossas vidas" (Chimisso 2017 192).
} 
em toda uma série de livros: a análise é o produto das ciências objetivas, das ciências obrigadas à ascese rigorosa de uma «psicanálise objetiva» que arranca o objeto de todas as suas ligações afetivas e sentimentais. Bachelard verifica inúmeras vezes que os fulcros da ciência e da poesia são inversos (Durand 1993 63).

Por fim, é possível dizer que a hermenêutica dos sonhos em Bachelard é criadora e instauradora, como uma decifradora ampliadora de sentido e não redutora, que explicaria o ser humano pelo passado. Segundo a Prof ${ }^{a}$ Constança Marcondes, "A hermenêutica de Bachelard propõe uma ontologia do ser humano, entendido como "ser entreaberto', anima com direito ao sonho" (Cesar 1975 13). Contudo, para se chegar a essa compreensão muitas vezes é preciso primeiro passar pela meditação dos sentidos entre o mundo e os objetos de conhecimento interpretados por Bachelard e nisso os modelos interpretativos são incessantemente corrigidos e retificados. Assim, é preciso sempre relembrar um sentido nunca é suficiente, é preciso um pluralismo que dinamize a consciência entre hermenêuticas opostas, e assim libertar a palavra para enfim induzir o que "podemos ver uma aplicação sistematizada do que Bachelard pressentia na felicidade da leitura, no equilíbrio reencontrado pelo «sonhador de palavras» (Durand 1993 100).

Por fim, gostaríamos de ressaltar que procuramos investigar hermeneuticamente diversas interpretações bachelardianas em culturas de língua portuguesa, inglesa, francesa e espanhola. Fomos das primeiras investigações sobre essa temática no Brasil, preconizadas principalmente pela Prof ${ }^{a}$. Constança Marcondes César até uma das abordagens mais recentes inglesas, onde a Prof ${ }^{a}$ Eileen Rizo-Patron tem uma importante representatividade com artigo "Bachelard's subversive hermeneutics". Nele, a autora desenvolveu uma espécie de círculo hermenêutico com outros pensadores como Bruce Kearney e os estudos da imaginação, ressaltando a influência de Bachelard em autores como Ricoeur ${ }^{16}$ e em certa via com Gadamer. 
Na medida em que a hermenêutica de Bachelard se concentra na emergência repentina de imagens poéticas na consciência de meros fragmentos de textos, enquanto preocupações de rupturas de obras como um todo ou em sua inserção na história, ele se coloca sob a linha direta de fogo do Gadamer na crítica da consciência estética moderna - ou seja, o tipo de consciência que de acordo com Gadamer se cumpre em "descontinuidade absoluta" ou na desintegração do objeto estético unitário em uma multiplicação de experiências subjetivas e impressionistas (Rizo-Patron 2006 356).

Gostaríamos de finalizar justificando que a problemática apresentada buscou tratar problema da hermenêutica em Bachelard como uma possibilidade de interpretação de imagens, isso não seria uma tarefa puramente fenomenológica, visto que nesse método Bachelard consiste na criação das imagens e a hermenêutica na interpretação. Nesse sentido, a relações de ruptura desse método com as ciências herméticas se dão num âmbito de uma hermenêutica epistemológica, que consequentemente seria o âmbito do Novo espírito científico e da Formação do espírito científico em que Bachelard considera essas dimensões do conhecimento como obstáculos da ciência. Por outro lado, ao fazer uma passagem de uma fenomenologia horizontal, em que o objeto se coloca como uma intimidade substancial, apreendida pela relação entre subjetividade e história, para uma fenomenologia vertical e aérea, cunhada numa nova interpretação literária ligada a unidade do inconsciente, dos sonhos e da psicologia da materialidade dos elementos. É daí que se esclarece que há uma continuidade entre hermetismo e hermenêutica na medida em

viva "Se a semântica reencontra aqui seu limite, uma fenomenologia da imaginação, como a de Bachelard, poderia tomar aqui o dispositivo da psicolinguística e repercurtirlhe o impulso nas zonas em que o não-verbal conduz ao verbal. Mas é ainda a semântica do verbo poético que se faz entender nessas profundidades. Aprendemos com Gaston Bachelard que a imagem não é um resíduo da impressão, mas uma aurora da palavra" (Ricoeur 2000 328). 
que se consiste numa leitura de imagens, e estas são anteriores aos conceitos e consequentemente desempenham um caráter revolucionário de ampliação da reflexão sobre as linguagens e a hermenêutica e consequentemente sua aproximação com a semiologia e os estudos do imaginário.

\section{Bibliografia}

Agualusa, José Eduardo. A vida no céu. Lisboa, Portugal: Quetzal Editores, 2013.

Bachelard, Gaston. O ar e os sonhos - Ensaio sobre a imaginação do movimento. São Paulo: Martins Fontes, 1990.

Bachelard, Gaston. A Poética do Espaço. Tradução de Antonio de Pádua Danesi. São Paulo: Martins Fontes, 1993.

Bolshaw, Marcelo. "Gaston Bachelard: e a metapoética dos quatro elementos", Estética (São Paulo), 11 (2015).

Bontemps, Vicent. Bachelard. Trad. de Nícia Adam Bonatti. São Paulo: Estação Liberdade, 2017.

Castro, Alfonso. "A poética de Gaston Bachelard". A poética de Manoel de Barros: a linguagem e a volta à infância, A, Castro. Brasilia: Unb, 1991.

Cesar, Constança. "Bachelard e as hermenêuticas contemporâneas". Reflexão, 1. Campinas: PUCCAMP (1975).

Chimisso, Cristina. "Gaston Bachelard's Places of the Imagination and Images of Space". Place, Space and Hermeneutics, Contributions to Hermeneutics, B.B. Janz (ed.). London: Springer International Publishing, 2017.

Derrida, Jacques. Margens da filosofia. Tradução Joaquim Torres Costa, António M. Magalhães; revisão técnica Constança Marcondes Cesar. Campinas, SP: Papirus, 1991.

Durand, Gilbert. A imaginação simbólica. Lisboa, Portugal: Ed. 70, 1993.

Ferreira, Agripina Encarnacion. Dicionário de imagens, símbolos, mitos, termos e conceitos Bachelardianos. Londrina: Eduel, 2013.

Lapoujade, Maria Noel. "Mito e imaginación a partir de la poética de Gastón Bachelard". Gaston Bachelard y la vida de las imágenes. Coleção Cuadernos de Hermenéutica, № 3. México: UNAM/Centro Regional de Investigaciones Multidisciplinarias, 2009. 
Miles, Kennedy. Bachelardian Concrete Metaphysics. Bern: Peter Lang, 2011.

Minett, Gunnel. Respiração e Espiritualidade - Rebirthing: Uma técnica de cura. Trad. Alípio Neto e Sandra Franca. São Paulo: Ed. Pensamento, 1994.

Ramnoux, Clemence. "Pour un nouveau tissu linguistique de la philosophie". Revue de Métaphysique et de Morale, 84/4 (Octobre-Décembre 1979): 521535.

Ricoeur, Paul. A metáfora viva. Trad. Dion Macedo. São Paulo: Ed. Loyola, 2000.

Rizo-Patron, Eileen. "Bachelard's Subversive Hermeneutic: A Reading of 'lightining' in Shelley's Prometheus Unbond". Religion and the Arts 10/3. Leiden (2006): 355-373.

Rocha, Gabriel. "A filosofia da Astrologia: Uma investigação entre Pico della Mirandola e Bachelard". Revista Eletrônica do Mestrado de Educação Ambiental 33/1 (2016): 95-111.

Senicato, Renato \& Silva, Luzia. "A fenomenologia hermenêutica de Gaston Bachelard: Apontamentos Esparsos". Pibid na pedagogia do cotidiano escolar: Experiências formativas, Estrada, Wendling \& Alves. Porto Alegre: Unioeste, 2016.

Serres, Michel. Luzes: Cinco Entrevistas com Bruno Latour. Trad. Luiz Rouanet. São Paulo: Unimarco, 1999.

Silva, Luzia. "Fenomenologia e hermenêutica de Gaston Bachelard". Imaginário, poesia e educação, Luzia Silva y Cecília Meireles. São Paulo: Terceira Margem, 2011. 